\title{
Price Discrimination as a Marketing Strategy
}

\author{
M. J. Alhabeeb ${ }^{1}$ \\ ${ }^{1}$ University of Massachusetts Amherst, USA \\ Correspondence: Prof. M. J. Alhabeeb, University of Massachusetts Amherst, USA. E-mail: \\ mja@resecon.umass.edu
}

Received: August 10, 2019

Accepted: September 8, 2019 Online Published: September 29, 2019

doi:10.5539/ijms.v11n4p1

URL: https://doi.org/10.5539/ijms.v11n4p1

\begin{abstract}
Many empirical studies have confirmed the validity and utility of price discrimination as a tool to attract more customers, increase sales, and boost revenues and profits. Several of these studies found strong market evidence of both second and third-degree price discrimination. This study confirms that price discrimination would not only work for monopolistic firms, as we have learned in the classic economic analysis, but also works effectively as essential element in a marketing strategy, especially for companies which adhere to the marketing principles on consumer satisfaction. This study also examines the utilization of price discrimination as a marketing tool by presenting the underlying theory and offering illustrative numerical examples. It further shows the different forms in which price discrimination comes in, the appropriate products eligible for price discrimination, the fields where such a strategy is applied, and the empirical studies involved.
\end{abstract}

Keywords: price discrimination, marketing strategy, marketing performance, consumer segmentation

\section{Introduction}

It was the English economist Arthur Cecil Pigou (1877-1959) of the University of Cambridge who introduced the idea of price discrimination back in 1920 in the context of his theory of welfare economics. Later in 1933, another English economist of Cambridge, Joan Robinson (1903-1983) discussed further the notion of price discrimination in her classic analysis of market, specifically monopoly and monopolistic competition, as part of her study of the economics of imperfect competition.

Later on, the topic of multi-prices of the same product became regular in classic economics, and was discussed by many prominent economists such as George Stigler (1911-1991), particularly in his theory of price in 1942. Another Nobel laureate, Paul Samuelson also addressed price discrimination in his signature work, Foundation of Economic Analysis, back in 1946.

Many empirical studies have confirmed the validity and utility of price discrimination as a tool to attract more customers, increase sales, and boost revenues and profits. Several of these studies found strong market evidence of both second and third-degree price discrimination (McManus, 2007; Clerides, 2008). La Croix (1984) went further to state unambiguously that a firm's use of coupon pricing (as a form of price discrimination) led to an increase in the good's output and to an improvement in welfare (p. 847). Price discrimination would not only work for monopolistic firms, as we have learned in the classic economic analysis, but also works effectively as essential element in a marketing strategy for companies which adopt the marketing approach of management that aims for maximizing consumer satisfaction as well as maximizing firm's profits. Netseva-Porcheva (2013) emphasized that third-tier price discrimination, whether alone or jointly with second-tier price discrimination can be used in a company marketing management in order to increase the company's revenues and profits, while first-tier price discrimination remains inapplicable in the field of marketing because it runs counter to its basic principles (p. 51; 62).

While this paper concurs with and confirms Netseva-Porcheva's view, it examines the utilization of price discrimination as a marketing tool by presenting the underlying theory and offering illustrative numerical examples. It also shows the different forms in which price discrimination comes in, the fields and products where these forms are applied, and the empirical studies involved.

\section{Theory and Applications in Marketing}

Price discrimination refers to charging different prices of a product or service for different customers, different 
markets, different quantities and different time. The price difference has to be a non-cost based. The major objective for this practice is to take the opportunities to increase revenue and ultimately maximize profits. In a more technical term, it is a managerial/marketing strategy to efficiently capture the highest of the consumer surplus by extracting the maximum amount each customer is willing to pay. Typical examples of price discrimination practice which we commonly encounter are the phone services that charge different rates based on the time of day or week and also charge higher rates for businesses than for individuals; the quantity discounts that are offered to buyers of large amounts; the medical and legal services that are offered based on customer's income scale; restaurants, transportation, and entertainment services that are offered favorably to elderly and children; power services that are sold in lower rates to local businesses; hotels and resorts with lower rates for conventions and conferences, and so on. There are conditions that must be met for a firm to practice price discrimination. Most crucial of these conditions are: 1) the producing firm has to be imperfectly competitive for it has to have a full control over the price. 2) The basis of differences such as time, quantity, customer, must be separable. 3) The market must be segmentable, and 4) the price elasticity of demand has to be different according to all of the bases of differences such as different quantities of product, different customers, and different time.

There are three types of price discrimination: the first degree (or perfect) discrimination, the second degree, and third degree of price discrimination.

\subsection{First-Degree Price Discrimination}

This type is based on the assumption that if a producer (a monopolist) can sell each unit of a product separately and charge the price that a consumer is willing to pay, most likely after some haggling. In this case, the producer would be able to capture all of the consumer surplus, the revenue would be the highest, and profit would be the absolute maximum, given a certain average cost of the product.

Let's look at Figure 1 and recall that if the equilibrium price is $\mathrm{P}_{\mathrm{e}}$ there would have been some consumers who were willing to pay higher prices such as $\mathrm{P}_{3}, \mathrm{P}_{4}, \mathrm{P}_{5}$ but for lower quantities and there were some willing to pay lower prices $\left(\mathrm{P}_{2}, \mathrm{P}_{1}\right)$ for more quantities.

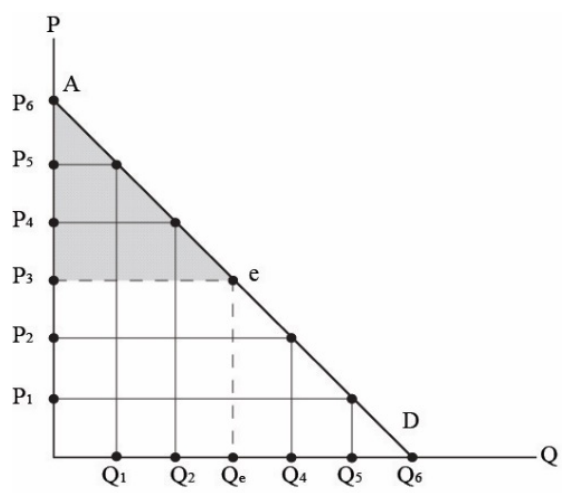

Figure 1. Consumer Surplus 1

The essence of consumer surplus centers around the value of benefits that aconsumer would receive in excess of what he pays for. It can be seen as equal to the triangle ( $\mathrm{Ae} \mathrm{Pe}$ ) because what the consumer was willing to pay was equal to the entire area of (Ae Qe 0 ) to get a quantity equal to $Q_{e}$, but the consumer ended up paying what is equal to the area (Pe e Qe 0).

According to the first degree of price discrimination, a monopolist can take back all of the consumer surplus if he is able to sell each unit of the product separately and change the prices that specific consumers are willing to pay. This type of price discrimination is rare to find in the practical world but its analysis is still important for it illustrates the essence of price differentials.

Technically, the consumer surplus (CS) can be explained by:

$$
\mathrm{CS}=\sum_{\mathrm{i}=1}^{\mathrm{n}}\left(\mathrm{P}_{\mathrm{i}} \Delta \mathrm{Q}_{\mathrm{i}}\right)=\mathrm{P}_{\mathrm{n}} \mathrm{Q}_{\mathrm{n}}
$$


where $P_{n}$ is market price, $Q_{n}$ is the quantity demanded by consumer $i . P_{i}$ and $Q_{i}$ re the price and quantity in the following individual demand function which is assumed to be linear:

Substituting for the function, we get:

$$
\mathrm{P}_{\mathrm{i}}=\alpha+\beta \mathrm{Q}_{\mathrm{i}}
$$

$$
\mathrm{CS}=\sum_{\mathrm{i}=1}^{\mathrm{n}}\left[\left(\alpha+\beta \mathrm{Q}_{\mathrm{i}}\right) \Delta \mathrm{Q}_{\mathrm{i}}\right]-\mathrm{P}_{\mathrm{n}} \mathrm{Q}_{\mathrm{n}}
$$

Consumer surplus such as the triangle Ae Pe in Figure 11.7 can be better estimated as $\Delta \mathrm{Q}_{\mathrm{i}}$ becomes smaller and smaller. Considering the linear demand function and as $\Delta \mathrm{Q}$ approaches zero, consumer surplus (CS) would be calculated as:

$$
\mathrm{CS}=\frac{1}{2}\left[\alpha-\mathrm{P}_{\mathrm{n}}\right] \mathrm{Q}_{\mathrm{n}}
$$

To illustrate with numerical values, let's suppose that a demand function is expressed by:

$$
\mathrm{P}_{\mathrm{i}}=60-6 \mathrm{Q}_{\mathrm{i}}
$$

Also suppose that market price $\left(\mathrm{P}_{\mathrm{n}}\right)$ is $\$ 18.00$ and the change in quantity $(\Delta \mathrm{Q})$ is 1 . We can find consumer surplus as:

$$
\mathrm{CS}=\sum_{\mathrm{i}=1}^{\mathrm{n}}\left(\mathrm{P}_{\mathrm{i}} \Delta \mathrm{Q}_{\mathrm{i}}\right)-\mathrm{P}_{\mathrm{n}} \mathrm{Q}_{\mathrm{n}}
$$

Given that $\Delta \mathrm{Q}=1, \mathrm{P}_{\mathrm{n}}=18$, and $\mathrm{Q}_{\mathrm{n}}$ is $\mathrm{Q}_{\mathrm{i}}$ and can be obtained from the demand function:

$$
\begin{gathered}
6 \mathrm{Q}_{\mathrm{i}}=60-\mathrm{P}_{\mathrm{i}} \\
\mathrm{Q}_{\mathrm{i}}=\frac{60}{6}-\frac{18}{6} \\
\mathrm{Q}_{\mathrm{i}}=10-3=7 \\
\mathrm{CS}=\sum_{\mathrm{i}=1}^{\mathrm{n}}\left[60-6 \mathrm{Q}_{\mathrm{i}}\right](1)-(18)(7) \\
\mathrm{CS}=\sum_{\mathrm{i}=1}^{7}[(60-6(1))+(60-6(2))+(60-6(3))+(60-6(4)+(60-6(5))+(60-6(6)+(60-6(7))]-126 \\
=[54+48+42+36+30+24+18]-126 \\
=126
\end{gathered}
$$

and for $\Delta \mathrm{Q}$ approaching

$$
\begin{aligned}
\mathrm{CS} & =\frac{1}{2}\left[\alpha-\mathrm{P}_{\mathrm{n}}\right] \mathrm{Q}_{\mathrm{n}} \\
& =\frac{1}{2}[60-18) 7 \\
& =(30-9) 7=147
\end{aligned}
$$

This means that the more accurate value of consumer surplus is 147 since the change in $Q$ was approaching zero and the 126 is an approximate value for the consumer surplus as the change in Q was assumed as equal to 1 .

\subsection{Second-Degree Price Discrimination}

This type is relatively more common than the first-degree price discrimination. It is about setting prices based on the quantity purchased. Differential prices are charged by blocks, such as charging the highest price per unit for the block at the top of the demand curve, and progressively lowering the price for the blocks after the first one 
and towards the bottom of the demand curve. According to this marketing strategy, a firm would only extract part of the consumer surplus, but still, it is a practice aiming at maximizing revenues and profits. Power, gas and water companies are known to adopt this second-degree price discrimination by offering a higher block rate for certain size of consumption but it gets lower per unit as the size of consumption increases. This practice is still generally limited, although it is more common than the first-degree price discrimination. It requires that the firms know more details about the demand curves of their consumers. Also, it requires that the product consumption can be metered such as in the case of public utilities.

The second-degree price discrimination is also expressed in the block pricing of fixed quantities such as the six-pack soft drink or beer cans or eight or sixteen-bun package and alike. This marketing practice works easily for the firm as profit maximizer. Let's take, for example, the case of six-pack soda cans. Suppose that the demand function is

$$
\mathrm{P}=.9-.0375 \mathrm{Q}
$$

and the marginal cost per can is fixed at 30 cents.

The retailer's block price (BP) would be to add the consumer surplus to the total revenue of the 6 cans:

$$
\begin{gathered}
\mathrm{TR}=\mathrm{P} . \mathrm{Q} \\
=(.3)(6)=1.80 \\
\mathrm{CS}=\frac{1}{2}\left[\alpha-\mathrm{P}_{\mathrm{r}}\right] \mathrm{Q}_{\mathrm{n}} \\
=\frac{1}{2}[.9-.3] 6 \\
=1.80 \\
\mathrm{BP}=\mathrm{TR}+\mathrm{CS} \\
=1.80+1.80=3.60
\end{gathered}
$$

The retailer would make the following profit given that the total cost is:

$$
\begin{aligned}
\mathrm{TC} & =\mathrm{MC} . \mathrm{Q} \\
& =(.30)(6)=1.80 \\
\mathrm{Pr} & =\mathrm{BP}-\mathrm{TC} \\
& =3.60-1.80=1.80
\end{aligned}
$$

This marketing practice would then achieve a profit that is $100 \%$ of the total cost.

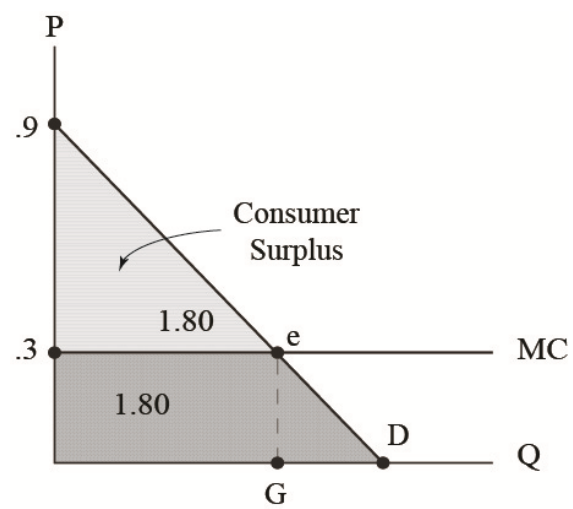

Figure 2. Consumer Surplus 2

\subsection{Third-Degree Price Discrimination}

This type of price discrimination occurs when an imperfectly competitive firm adopts a marketing strategy to distinctively segment the market into different segments and charges them different prices for the same product. Classic examples of this price discrimination are represented by marketing practices that would extend a 
seemingly goodwill-driven and community-spirited discounts such as those offered to seniors, kids, students, veterans or any other market segment that is distinguished by a certain characteristic such as age, profession, marital status, and alike. This strategy would also include market segments distinguished by time of consumption, especially in the case of movie tickets or vacation packages. It is assumed that charging different prices for different markets is practiced until the marginal revenue in each market equals the marginal cost of producing the product. This is to say that the profit maximizing condition would be:

$$
\mathrm{MC}=\mathrm{MR}_{1}=\mathrm{MR}_{2}=\ldots \ldots=\mathrm{MR}_{\mathrm{n}}
$$

where $\mathrm{n}$ refers to the number of markets for different segments. For this type of discrimination to be valid, a firm is required to: 1) be able to control prices. it is to say that the firm cannot be a price taker; 2) be able to know and identify demand functions for all the market segments, subject to this type of discrimination; 3) be able to know that those market segments have different price elasticity of demand, which would be the basis of variation in the price such that the segment exhibiting a higher price elasticity of demand would be charged the lower price, and the segment exhibiting a lower price elasticity of demand would be charged a higher price.

This would provide an explanation of seeing a lower electricity rates granted to the business sector and a higher rate to the residential sector; lower hotel rates for members of a big convention than for ordinary customers, and so on; 4) be able to distinguish the consumers in each market segment based on a certain characteristic such as age, profession, marital status and alike; 5) be able to rule out any potential arbitrage. That is to insure that there would be no potential trade among the segments in the market so that the group enjoying the lower price cannot sell products to those paying a higher price. Needless to say, that if such a case is to happen, the whole purpose of price discrimination would be defeated.

Technically, we can see how different price elasticities of demand leads to justifying prices in inverse relationships to the elasticities.

Assuming there are two market segments so that the firm output $(\mathrm{Q})$ would be distributed to both segments $\left(\mathrm{Q}_{1}\right)$ and $\left(\mathrm{Q}_{2}\right)$ :

$$
\mathrm{Q}=\mathrm{Q}_{1}+\mathrm{Q}_{2}
$$

and the total and marginal revenues for the firm would be:

$$
\begin{gathered}
\mathrm{TR}=\mathrm{P} \cdot \mathrm{Q} \\
\mathrm{MR}=\frac{\mathrm{dTR}}{\mathrm{dQ}} \\
\mathrm{MR}=\frac{\mathrm{dPQ}}{\mathrm{dQ}} \\
\mathrm{MR}=\mathrm{P}+\mathrm{Q}\left[\frac{\mathrm{dP}}{\mathrm{dQ}}\right]
\end{gathered}
$$

Factoring P out, we get:

$$
\mathrm{MR}=\mathrm{P}\left[1+\frac{\mathrm{Q}}{\mathrm{P}}\left(\frac{\mathrm{dP}}{\mathrm{dQ}}\right)\right]
$$

given that the price elasticity of demand is defined as:

$$
E=\frac{d Q}{d p} \cdot \frac{P}{Q}
$$

the term inside the bracket would be the reverse of elasticity, 


$$
\mathrm{MR}=\mathrm{P}\left[1+\frac{1}{\varepsilon}\right]
$$

Since we assumed that there are two market segments with their own marginal revenues, $\mathrm{MR}_{1}$ and $\mathrm{MR}_{2}$, their own prices $\mathrm{P}_{1}$ and $\mathrm{P}_{2}$, and their own elasticities $\varepsilon_{1}$ and $\varepsilon_{2}$, and that we equate the marginal revenues, we can obtain:

$$
\begin{array}{r}
\mathrm{MR}_{1}=\mathrm{MR}_{2} \\
\mathrm{P}_{1}\left[1+\frac{1}{\varepsilon_{1}}\right]=\mathrm{P}_{2}\left[1+\frac{1}{\varepsilon_{2}}\right] \\
\frac{\mathrm{P}_{1}}{\mathrm{P}_{2}}=\frac{\left[1+\frac{1}{\varepsilon_{2}}\right]}{\left[1+\frac{1}{\varepsilon_{1}}\right]}
\end{array}
$$

This means that if $\mathrm{P}_{1}>\mathrm{P}_{2}$, then $1+\frac{1}{\varepsilon_{1}}$ and therefore $\varepsilon_{1}$ has to be smaller than $1+\frac{1}{\varepsilon_{2}}$ and therefore smaller than $\varepsilon_{2}$. Also, if $\mathrm{P}_{1}<\mathrm{P}_{2}$, then $1+\frac{1}{\varepsilon_{1}}$ and therefore $\varepsilon_{1}$ has to be larger than $1+\frac{1}{\varepsilon_{2}}$ and therefore larger than $\varepsilon_{2}$. It is simply to say prices and price elasticities of demand has the opposite relationship. This is why higher prices are charged on the product whose price elasticity of demand is low, and lower prices are charged on the product whose price elasticity of demand is high. To confirm, let's give any random numerical values to elasticities and see if they result in the inverse relationship to prices. Let's suppose that product $x$ has a price elasticity of demand equal to -2 and product y has a price elasticity of demand equal to -4 . Substituting these values into equation (1), we get

$$
\begin{gathered}
\frac{\mathrm{P}_{\mathrm{x}}}{\mathrm{P}_{\mathrm{y}}}=\frac{\left[1+\frac{1}{\varepsilon_{\mathrm{y}}}\right]}{\left[1+\frac{1}{\varepsilon_{\mathrm{x}}}\right]} \\
\frac{\mathrm{P}_{\mathrm{x}}}{\mathrm{P}_{\mathrm{y}}}=\frac{\left[1+\frac{1}{-4}\right]}{\left[1+\frac{1}{-2}\right]} \\
\frac{\mathrm{P}_{\mathrm{x}}}{\mathrm{P}_{\mathrm{y}}}=\frac{\frac{3}{4}}{\frac{1}{2}}
\end{gathered}
$$




$$
\begin{gathered}
\frac{1}{2} \mathrm{P}_{\mathrm{x}}=\frac{3}{4} \mathrm{P}_{\mathrm{y}} \\
\mathrm{P}_{\mathrm{x}}=\frac{\frac{3}{4}}{\frac{1}{2}} \mathrm{P}_{\mathrm{y}} \\
\mathrm{P}_{\mathrm{x}}=1.5 \mathrm{P}_{\mathrm{y}}
\end{gathered}
$$

So, $\mathrm{P}_{\mathrm{x}}>\mathrm{P}_{\mathrm{y}}$ while $\varepsilon_{\mathrm{x}}<\varepsilon_{\mathrm{y}}$ or $|2|<|4|$. We can also illustrate that graphically as it is shown in Figure 3. There are three panels, one for each market and the third is for the total market. Both the demand curve and the marginal revenue curve show through their slopes that market 1 is more price inelastic (less elastic) with steeper $\mathrm{D}_{1}$ and $\mathrm{MR}_{1}$. Market 2 is less price inelastic (more elastic) and therefore having flatter $\mathrm{D}_{2}$ and $\mathrm{MR}_{2}$.
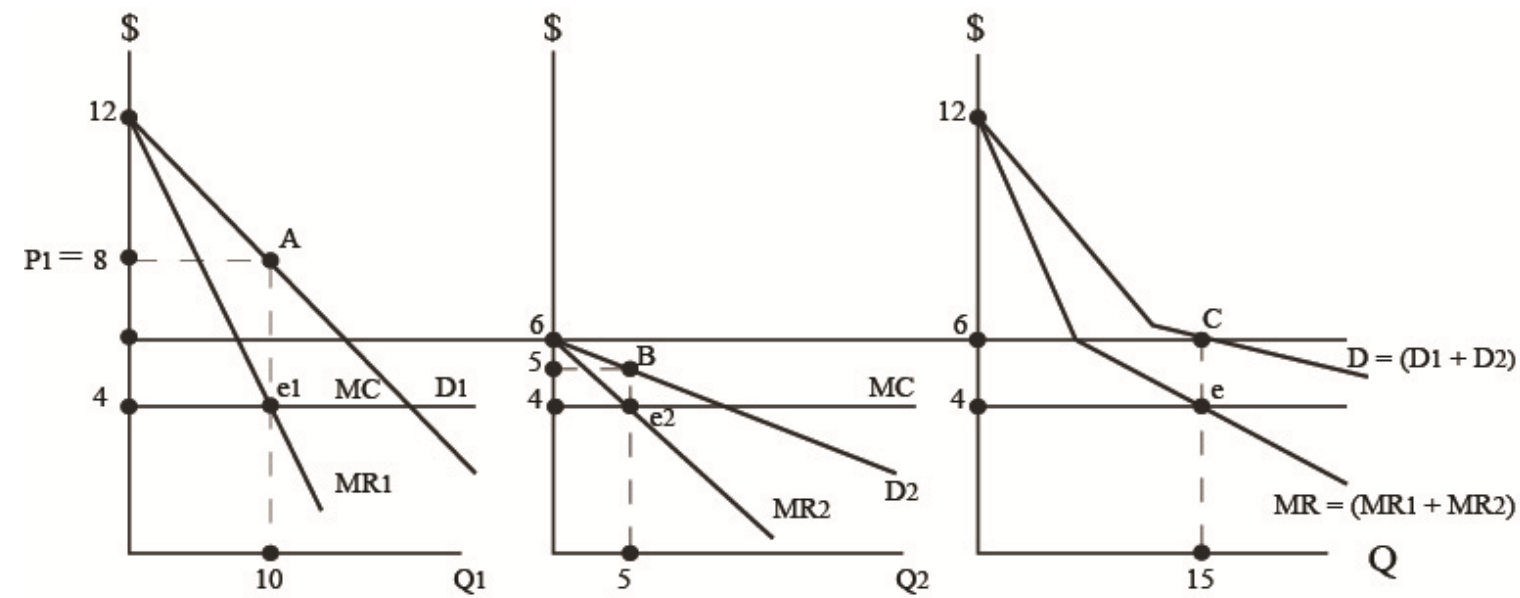

Figure 3. Markets and elasticity of demand

The whole market in the far right, third panel shows the market demand D and market marginal revenue MR as horizontal summations of the demand curve and marginal revenue in both markets. As we have seen algebraically that when the marginal revenue equals the marginal cost we get the equilibrium quantities and prices. In the first market, the equilibrium output turned out to be 10 and the equilibrium price was $\$ 8.00$ as it was determined from point $A$ on $D_{1}$. Also, in the second market, the equality between $\mathrm{MR}_{2}$ and $\mathrm{MC}$ produced the optimal output level 5 which is sold at $\$ 5.00$ per unit as it was determined by point $\mathrm{B}$ on $\mathrm{D}_{2}$. The marginal cost remained fixed at $\$ 4.00$ in all markets. As for the whole market, point e is the equality point between market marginal revenue and marginal cost. The optimal market output is 15 which is the combination of outputs in both markets. Market price would be determined from point $\mathrm{C}$ on $\mathrm{D}_{3}$ as $\$ 6.00$.

It is also confirmed graphically that the less price elastic market 1 charges the higher price, $\$ 8.00$, and the more price elastic market 2 charges the lower price, $\$ 5.00$. Once again, the highest profit is achieved through the two price-discriminated markets rather than one unfixed market.

As a numerical example, let's look at the following two demand functions and a total cost function for a product sold in two different market segments. If the marginal cost remains fixed at $\$ 4.00$ through the markets, will the $3^{\text {rd }}$-degree price discrimination yield higher or lower profit levels?

$$
\mathrm{Q}_{1}=30-\frac{5}{2} \mathrm{P}_{1}
$$




$$
\begin{gathered}
\mathrm{Q}_{2}=30-5 \mathrm{P}_{2} \\
\mathrm{TC}=22.50+2\left(\mathrm{Q}_{1}+\mathrm{Q}_{2}\right)
\end{gathered}
$$

Before we write the total revenue functions in both markets, we need to express the demand functions in terms of the prices:

$$
\begin{aligned}
& \mathrm{P}_{1}=12-\frac{2}{5} \mathrm{Q}_{1} \\
& \mathrm{P}_{2}=6-\frac{1}{5} \mathrm{Q}_{2} \\
& \mathrm{TR}_{1}=\mathrm{Q}_{1} \mathrm{P}_{1} \\
& \mathrm{TR}_{1}=\mathrm{Q}_{1}\left[12-\frac{2}{5} \mathrm{Q}_{1}\right] \\
& \mathrm{TR}_{1}=12 \mathrm{Q}_{1}-\frac{2}{5} \mathrm{Q}_{1}^{2} \\
& \mathrm{MR}_{1}=\frac{\partial \mathrm{TR}_{1}}{\partial \mathrm{Q}_{1}}=12-\frac{4}{5} \mathrm{Q}_{1} \\
& \mathrm{TR}_{2}=\mathrm{Q}_{2} \mathrm{P}_{2} \\
& \mathrm{TR}_{2}=\mathrm{Q}_{2}\left[6-\frac{1}{5} \mathrm{Q}_{2}\right] \\
& \mathrm{TR}_{2}=6 \mathrm{Q}_{2}-\frac{1}{5} \mathrm{Q}_{2}^{2} \\
& \mathrm{MR}_{2}=\frac{\partial \mathrm{TR}_{2}}{\partial \mathrm{Q}_{2}}=6-\frac{2}{5} \mathrm{Q}_{2}
\end{aligned}
$$

The profit-maximizing conditions in both markets are achieved by equating both revenues to the same marginal cost of the product.

$$
\begin{gathered}
\mathrm{MR}_{1}=\mathrm{MC} \\
12-\frac{4}{5} \mathrm{Q}_{1}=4 \\
8=\frac{4}{5} \mathrm{Q}_{1} \\
\mathrm{Q}_{1}=10 \\
\mathrm{P}_{1}=12-\frac{2}{5} \mathrm{Q}_{1}
\end{gathered}
$$




$$
\begin{aligned}
& \mathrm{P}_{1}=12-\frac{2}{5}(10)=8 \\
& \mathrm{MR}_{2}=\mathrm{MC} \\
& 6-\frac{2}{5} Q_{2}=4 \\
& 2=\frac{2}{5} \mathrm{Q}_{2} \\
& \mathrm{Q}_{2}=5 \\
& \mathrm{P}_{2}=6-\frac{1}{5} \mathrm{Q}_{2} \\
& \mathrm{P}_{2}=6-\frac{1}{5}(5)=5 \\
& \mathrm{TR}_{1}=12 \mathrm{Q}_{1}-\frac{2}{5} \mathrm{Q}_{1}^{2} \\
& \mathrm{TR}_{1}=12(10)-\frac{2}{5}(10)^{2} \\
& \mathrm{TR}_{1}=80 \\
& \mathrm{TR}_{2}=6 \mathrm{Q}_{2}-\frac{1}{5} \mathrm{Q}_{2}^{2} \\
& \mathrm{TR}_{2}=6(5)-\frac{1}{5}(5)^{2} \\
& \mathrm{TR}_{2}=25 \\
& \mathrm{TR}=\mathrm{TR}_{1}+\mathrm{TR}_{2} \\
& \mathrm{TR}=80+25=105 \\
& \mathrm{TC}=22.50+2\left(\mathrm{Q}_{1}+\mathrm{Q}_{2}\right) \\
& =22.50+2(10+5)=52.50 \\
& \mathrm{Pr}=\mathrm{TR}-\mathrm{TC} \\
& \operatorname{Pr}=105-52.50=52.50
\end{aligned}
$$

So, the profit under the price discrimination practice is $\$ 52.50$. What would it be if this practice is not followed, that is if there is only one market?

$$
\begin{gathered}
\mathrm{Q}=\mathrm{Q}_{1}+\mathrm{Q}_{2} \\
\mathrm{Q}=30-\frac{5}{2} \mathrm{P}_{1}+30-5 \mathrm{P}_{2}
\end{gathered}
$$

Since there would be only one price, we substitute both $\mathrm{P}_{1}$ and $\mathrm{P}_{2}$ with $\mathrm{P}$ : 


$$
\begin{aligned}
& \mathrm{Q}=60-\frac{15}{2} \mathrm{P} \\
& \mathrm{P}=8-\frac{2}{15} \mathrm{Q} \\
& \mathrm{TR}=\mathrm{Q} . \mathrm{P} \\
& \mathrm{TR}=\mathrm{Q}\left[8-\frac{2}{15} \mathrm{Q}\right] \\
& \mathrm{TR}=8 \mathrm{Q}-\frac{2}{15} \mathrm{Q}^{2} \\
& \mathrm{MR}=\frac{\partial \mathrm{TR}}{\partial \mathrm{Q}}=8-\frac{4}{15} \mathrm{Q} \\
& \mathrm{MR}=\mathrm{MC} \\
& 8-\frac{4}{15} \mathrm{Q}=4 \\
& \frac{4}{15} \mathrm{Q}=4 \\
& \mathrm{Q}=15 \\
& \mathrm{P}=8-\frac{2}{15} \mathrm{Q} \\
& \mathrm{P}=8-\frac{2}{15}(15)=6 \\
& \mathrm{TR}=8(15)-\frac{2}{15}(15)^{2} \\
& \mathrm{TR}=90 \\
& \mathrm{TC}=22.50+2\left(\mathrm{Q}_{1}+\mathrm{Q}_{2}\right) \\
& =22.50+2 \mathrm{Q} \\
& =22.50+2(15)=52.50 \\
& \mathrm{Pr}=\mathrm{TR}-\mathrm{TC} \\
& \operatorname{Pr}=90-52.50=37.50
\end{aligned}
$$

So, the profit when price discrimination is practiced (\$52.50) is higher than without price discrimination (37.50). For another example, let's suppose a firm is selling its product in two separate markets as a third-degree price discrimination practice. The demand functions and total cost function are:

$$
\mathrm{Q}_{1}=120-2.4 \mathrm{P}_{1}
$$




$$
\begin{aligned}
& \mathrm{Q}_{2}=180-6 \mathrm{P}_{2} \\
& \mathrm{TC}=40+10 \mathrm{Q}
\end{aligned}
$$

We can find the firm's profit maximizing output and price, and calculate the total profits under the third-degree price discrimination. Also, we can show that the higher price is charged at the lower price elasticity market and the lower price is charged at the higher price elasticity market.

First, we express the demand functions in terms of price so we can calculate the total revenues:

$$
\begin{aligned}
& \mathrm{P}_{1}=50-.4167 \mathrm{Q}_{1} \\
& \mathrm{TR}_{1}=\mathrm{Q}_{1} \mathrm{P}_{1} \\
& \mathrm{TR}_{1}=\mathrm{Q}_{1}\left[50-.4167 \mathrm{Q}_{1}\right] \\
& \mathrm{TR}_{1}=50 \mathrm{Q}_{1}-.4167 \mathrm{Q}_{1}^{2} \\
& \mathrm{P}_{2}=30-.167 \mathrm{Q}_{2} \\
& \mathrm{TR}_{2}=\mathrm{Q}_{2} \mathrm{P}_{2} \\
& \mathrm{TR}_{2}=\mathrm{Q}_{2}\left[30-.167 \mathrm{Q}_{2}\right] \\
& \mathrm{TR}_{2}=30 \mathrm{Q}_{2}-.167 \mathrm{Q}_{2}^{2} \\
& \mathrm{TR}=\mathrm{TR}_{1}+\mathrm{TR}_{2} \\
& \mathrm{TR}_{2}=50 \mathrm{Q}_{1}-.4167 \mathrm{Q}_{1}^{2}+30 \mathrm{Q}_{2}-.167 \mathrm{Q}_{2}^{2} \\
& \mathrm{TC}=40+10 \mathrm{Q} \\
& \mathrm{TC}=40+10\left(\mathrm{Q}_{1}+\mathrm{Q}_{2}\right) \\
& \mathrm{TC}=40+10 \mathrm{Q}_{1}+10 \mathrm{Q}_{2} \\
& \mathrm{Pr}=\mathrm{TR}-\mathrm{TC} \\
& \operatorname{Pr}=50 \mathrm{Q}_{1}-.4167 \mathrm{Q}_{1}^{2}+30 \mathrm{Q}_{2}-.167 \mathrm{Q}_{2}^{2}-40-10 \mathrm{Q}_{1}-10 \mathrm{Q}_{2} \\
& \frac{\partial \operatorname{Pr}}{\partial Q_{1}}=50-.8334 Q_{1}-10=0 \\
& 40=.8334 \mathrm{Q}_{1} \\
& \mathrm{Q}_{1}=48 \\
& \mathrm{P}_{1}=50-.4167 \mathrm{Q} \\
& \mathrm{P}_{1}=50-.4167(48)=\$ 30 \\
& \frac{\partial \mathrm{Pr}}{\partial \mathrm{Q}_{2}}=30-.334 \mathrm{Q}_{2}-10=0 \\
& .334 \mathrm{Q}_{2}=20 \\
& \mathrm{Q}_{2}=60 \\
& \mathrm{P}_{2}=30-.167 \mathrm{Q}_{2} \\
& \mathrm{P}_{2}=30-.167(60)=\$ 20 \\
& \operatorname{Pr}=50(48)-.4167(48)^{2}+30(60)-.167(60)^{2}-40-10(48)-10(60) \\
& \operatorname{Pr}=1,519 \\
& \mathrm{Q}_{1}=120-2.4 \mathrm{P}_{1}
\end{aligned}
$$




$$
\begin{gathered}
\frac{\mathrm{dQ}_{1}}{\mathrm{dP}_{1}}=-2.4 \\
\varepsilon_{1}=\left[\frac{\mathrm{dQ}_{1}}{\mathrm{dP}_{1}}\right]\left[\frac{\mathrm{P}_{1}}{\mathrm{Q}_{1}}\right] \\
=(-2.4)\left[\frac{30}{48}\right]=-1.5 \\
\mathrm{Q}_{2}=180-6 \mathrm{P}_{2} \\
\frac{\mathrm{dQ}_{2}}{\mathrm{dP}_{2}}=-6 \\
\varepsilon_{2}=\left[\frac{\mathrm{dQ}}{\mathrm{dP}_{2}}\right]\left[\frac{\mathrm{P}_{2}}{\mathrm{Q}_{2}}\right] \\
\varepsilon_{2}=-6\left[\frac{20}{60}\right]=-2
\end{gathered}
$$

In absolute value, $\varepsilon_{2}>\varepsilon_{1}$ or market 2 has more price elasticity of demand than market 1 . Also, market 2 has a lower price, $\$ 20.00$, as compared to the $\$ 30.00$ in market 1 . This verifies that a higher price is charged at the market with lower price elasticity of demand, and a lower price is charged at the market with higher price elasticity of demand.

\section{Forms of Price Discrimination, Products, and Consumers}

There are many forms in which price discrimination comes in play as a tool. Marketing strategists would choose the right form depending on many factors such as, the nature of product, type and size of market, competing products, targeted consumers, and time variety. Price discrimination strategy has been successful in many fields and industries such as Travel and tourism, airline industry, food service, retail industry, pharmaceutical, textbook publishing and more.

As mentioned earlier, first-degree price discrimination is based on charging every unit of a product individually and separately to capture the maximum surplus out of a specific consumer. We do not witness this type of price discrimination very often in day to day life, but it could occur in a field of unique product such as certain kind of antique goods and valuables or special edition cars and alike where there is a single dealer and specifically interested number of consumers. The dealer would price the same item differently for different buyers based on his own perception of how to get the most out of each potential buyer he meets.

As for the second-degree price discrimination, there is a wide range of forms. The most common is the form that aims at enticing consumers to buy large quantities of a product by offering an attractive price, lower than the regular price, given the absence of any arbitrage (McAfee, 2008). Examples are:

1) bulk packages of a product as we see them at Costco purchases, for instance, and at many major grocery stores.

2) buy one- get one free, and similar forms such as buy two get one free or at a certain percentage discount; ten units of a product for ten dollars as the case we see often in a grocery store like ten cups of yogurt where if you buy them individually the price would be more than a dollar.

3) free product per certain number of purchases such as the case at a pizza stores which provides customers with a card that they punch in for each purchase. This method is not only to sell more but also to keep customers coming back to get the free pizza after a certain number of punches on the card, which is similar to another form which accumulate the discount.

4) cumulative discount, this is a certain price reward that won't be redeemed until after many purchases. Best 
example of that is the oil company which offers a certain discount of the last month of the season a customer fills up his oil tank. It is a successful marketing tactic to make customers stick with the firm until the end of the season.

5) Rebates which are used to promote the sale of certain products, usually at a significant discount. Anderson and Dana (2009) found that rebate strategy was more likely adopted by marketing strategists of a relatively disadvantaged firm compared to an obviously advantaged competitor, and therefore it was a price discrimination tool that benefited those firms with certain market disadvantage. Dogan et al. (2010) found that the more competition among firms of similar products the more beneficial is the price discrimination in the form of rebates. Consistent results found in the airline industry as far as the positive relationship between price discrimination and competition (Stavins, 2001; Borenstein \& Rose, 1994).

6) Coupons can be a second-degree price discrimination if the aim is purchasing more quantity of a product such as offering a percentage discount on two or three units. Also, coupons can be used to bundle other products, often a complementary good such as with the purchase of a coffee jar, the customer gets a discount of coffee filters. Coupons could also represent a third-degree price discrimination as it is explained below.

Time would be a determinant to practice a second- or third-degree price discrimination such as in the case of:

7) Peak and off-peak season or certain time of the week or day. Travel companies adjust their fairs before, during, and after major holidays such as Christmas and Thanksgiving. Time close to holidays usually means that consumer demand would be inelastic and any hike in the fair would most likely be accepted by customers. Borenstein and Rose (1994) confirmed a price discrimination in favor of the customer segment that tend to book up their flight early. Power and water companies may have different rates during a hot summer. Companies may increase the rate to rationalize demand on their product and relieve their limited capacity for supply. Telephone firms may also adjust their rates depending on time of the day and weekday/weekend.

Forms for the third-degree discrimination are usually shown in the discount for the "special" segment of consumers:

8) Segmenting consumers based on a certain aspect such as age groups: movie ticket discount or medicine discount for seniors; kids eat free or at half price. Other special groups who may qualify for discount of a certain product are students or veterans. Certain occupations can also be qualified for certain discounts such as books and supplies discount for teachers. Members of union, guild or certain association may qualify for a discount. Example is the AARP members who enjoy many discounts just for being in that group. Gender can be a factor to represent that special group for certain discount. Ladies night out is a good example of obtaining a good bargain at a night club on a certain day. As mentioned earlier, coupons discounts can be considered a form of third-degree price discrimination when the marketing tactic aims to attract a specific segment of customers such as those who are price-sensitive with elastic demand, or those who have time enough to spend on digging up and collecting coupons out of newspaper, magazines, and computer ads. Another example of the marketing tactics that spot certain segment of customers and aims for them is the trade-in form of price discrimination. Car dealers who offer to take an old car for a discount on a newer and better car know that they are attracting a certain group whose demand is elastic. Other examples of those customers who are very price-sensitive are those to rush to purchase when the sales are timed such as in a department store when they announce a significant sale on all furniture but only for the next four hours, or just on Monday. It became very familiar nowadays to see the type of discount online where a certain product is announced to be on a good sale but only based on first-order-first-served, given a limited supply. Obviously, it is designed to make those customers with elastic demand curves to rush to place their orders.

In their study of the market of academic journals, Phillips and Phillips (2002) showed the segmentation of subscribers between institutions and individuals where a price discrimination of a third degree was evident. A study of the same market by Zheng and Kaiser (2012) found the price discrimination was centered based on distinguishing the publishers as for-profit and non-profit. Other third-degree price discrimination was shown via dividing advertisements on the Yellow Pages based on the size of ads and their relative prices, where the larger size ads have prices that would fall more than the prices of smaller size ads (Busse \& Rysman, 2005).

\section{Conclusion}

Based on both theoretical and empirical evidence, this study would confirm that price discrimination, especially that of the second and third degree can be used as a tool at the disposal of marketing strategists, not only to sell more products and increase revenues and profits, but also to acquire more and different customers, enter more markets, promote different products, and still maintain customer satisfaction. Marketing strategies that utilize 
pricing tools would allow the firm to plan, implement, and monitor the impact of those strategies on sales and revenues and their changes, which may suggest certain revisions and modification. Those strategies often take into consideration the impact on what consumers can gain. Tomalieh (2014) found that practicing price discrimination by a group of five-star hotels improved their marketing performance as well as reached new guest's segments and increased their guest satisfaction. Those results of the study were consistent with other studies (Asplund et al., 2008; Baumol, 1982). Marketing strategists would aim at recommending a pricing plan that would enhance the overall marketing performance in its two integrative phases: 1) The plan effectiveness, which basically is concerned with executing the plan in all components which might include product development, customer acquisition, market share, customer satisfaction, and alike. 2) The plan efficiency which is to focus on how well is that execution of the plan in terms of cost and benefit. It involves quantitative and qualitative assessment of the execution via criteria such as sales and revenue, profitability, liquidity, return on investment and alike. Marketing performance in this sense, and due to applying any pricing policy such as price discrimination requires first and for most the firm to have marketing power, which is defined, according to Fisher (2008) as the firm's ability to price its product above its marginal cost.

Nowadays, with the prevalence of online sales and the wealth of information about products and their prices, price discrimination is expected to expand and in the same time become more challenging, especially to grab a market share and to watch more carefully the antitrust limitations.

\section{References}

Anderson, E., \& Dana, J. (2009). When is price discrimination profitable? Management Science, 55(6), 980-989.

Asplund, R., Erikssonz, N., \& Strand. (2008). Price Discrimination in Oligopoly: Evidence from Regional Newspapers. The Journal of Industrial Economics, LVI, 333-345.

Baumol, W. J. (1982). Contestable markets: an uprising in the theory of industry structure. American Economic Review, 72(1), 1-15.

Borenstein, S., \& Rose, N. (1994). Competition and price dispersion in the U.S. airline industry. Journal of Political Economy, 102(4), 653-683.https://doi.org/10.1086/261950

Busse, M., \& Rysman, M. (2005). Competition and Price Discrimination in Yellow Pages Advertising. Journal of Economics, 36, 378-390.

Clerides, S. (2002). Book Value: Intertemporal Pricing and Quality Discrimination in the U.S. Market for Books. International Journal of Industrial Organization, 20, 1385-1408. https://doi.org/10.1016/S0167-7187(02)00004-8

Dogan, K., Haruvy, E., \& Rao, R. (2010). Who should practice price discrimination using rebates in an asymmetric duopoly. $Q M E, 8(1), 61-90$. https://doi.org/10.1007/s11129-009-9078-8

Fisher, F. (2008). Detecting Market Power. In Issues in Competition Law and Policy.

La Croix, S. (1984). Marketing, Price Discrimination, and Welfare. Southern Economic Journal, 50(3), 847-852. https://doi.org/10.2307/1058004

McAfee, P. (2008). Price Discrimination. Issues in Competition Law and Policy, 465-484.

McManus, B. (2007). Nonlinear Pricing in an Oligopoly Market: The Case of Specialty Coffee. RAND Journal of Economics, 38, 512-532. https://doi.org/10.1111/j.1756-2171.2007.tb00081.x

Netseva-Porcheva, T. (2013). Application of the Price Discrimination in Marketing. Economic Alternatives, 3, 51-63.

Phillips, O., \& Lori, P. (2002). The market for academic journals. Applied Economics, 34, 39-48. https://doi.org/10.1080/00036840010029476

Pigou, A. (1920). The Economics of Welfare. London: Macmillan.

Robinson, J. (1969). The Economics of Imperfect Competition (2nd ed.). London: Macmillan. https://doi.org/10.1007/978-1-349-15320-6

Samuelson, P. (1983). Foundation of Economic Analysis (Enlarged ed.). Harvard Economic Studies.

Stavins, J. (2001). Price Discrimination in the Airline Market: The Effect of Market Concentration. The Review of Economics and Statistics, 83(1), 200-212. https://doi.org/10.1162/rest.2001.83.1.200

Tomalieh, E. F. (2014). The Effect of Applying Price Discrimination Strategy on the Marketing Performance of Five-star Hotels in Jordan. European Journal of Business and Management, 6(12), 137-144. 


\section{Copyrights}

Copyright for this article is retained by the author, with first publication rights granted to the journal.

This is an open-access article distributed under the terms and conditions of the Creative Commons Attribution license (http://creativecommons.org/licenses/by/4.0/). 